\title{
REMOVING THE INVASIVE TREE AILANTHUS ALTISSIMA AND RESTORING NATURAL COVER
}

\author{
by Patrick L. Burch' and Shepard M. Zedaker ${ }^{2}$
}

\begin{abstract}
Eight herbicide treatments were applied by lowvolume basal applications and compared to hand cutting for the removal of Ailanthus altissima. Manual cutting of Ailanthus stimulated resprouting and increased overall stand density. Chemical control not only removed existing trees but also prevented resprouting. When evaluated 2 years after treatment, optimal control of Ailanthus was achieved with a combination of Garlon 4 and Tordon K herbicides. Garlon 4 at $20 \%$ v/v alone, Garlon 4 combined with Stalker, or Stalker herbicide alone controlled Ailanthus better than hand cutting but were not as effective as treatments containing picloram. Removal of Ailanthus resulted in a shift in herbaceous species to native species of the region without reseeding with naturally occurring herbs. Manual control of Ailanthus should be avoided in order to prevent proliferation. Herbicide control of Ailanthus is the preferred method of control because it successfully kills the trees and prevents resprouting. Because major Ailanthus infestations occur near roadways, access with a backpack sprayer should be achievable.
\end{abstract}

Key Words. Ailanthus; invasive exotic tree; native vegetation; Tordon K picloram; Garlon 4 triclopyr; Stalker imazapyr; tree-of-heaven; herbicide control; manual cutting; tree ecology; allelopathy.

Ailanthus altissima (tree-of-heaven) is an invasive exotic weed tree that has become established throughout North

America. The state of Virginia, U.S., currently is experiencing a rapid invasion of Ailanthus along highways, utility rights-ofway, pastures, and disturbed forest sites. A recent survey of interstate highways in southwestern Virginia found that 30\% of the mileage along the highways was infested by Ailanthus (Stipes 1995). Ailanthus forms pure stands that shade out herbaceous growth and decrease native plant diversity. They also obstruct vistas along roadways as well as create a safety hazard by obstructing the view of drivers. A successful control method must be able to kill the Ailanthus stems and roots while allowing for the reestablishment of native vegetation on the site.

If ecological integrity is to be maintained in parks and other natural areas, invasive exotic species such as Ailanthus must be controlled within an acceptable limit. The purpose of this study was to test the effectiveness of herbicide tank mixes as low-volume basal applications on Ailanthus altissima. In the study, the efficacy of several different mixtures of Garlon $4^{\circledast}$ (triclopyr ester) plus Tordon $\mathrm{K}^{\circledast}$ (picloram salt) and Garlon 4 plus Stalker ${ }^{\circledast}$ (imazapyr), as well as Garlon 4 and Stalker alone were tested to determine effective treatments on Ailanthus. The effectiveness of manual cutting was also tested. Basal applications utilize oil-soluble herbicide formulations applied to the target stems in an oil carrier. Because no oil-soluble formulation of picloram is registered in the United States, the mixtures that contain Tordon $\mathrm{K}$ require adjuvants to remain in a single phase during application.

Past research has found that basal applications of herbicide mixtures can provide selective control of unwanted hardwood stems. Herbicides have different physiological pathways and modes of action. A mixture of Garlon 4 with Tordon K or Stalker at selected rates may provide aboveground stem dieback while also allowing translocation to the roots for complete control. In many instances, herbicide mixtures have been found to provide better control than single herbicides. There are no published studies involving basal applications of herbicide mixtures on Ailanthus altissima.

In Virginia, Shenandoah National Park is experiencing an invasion of Ailanthus altissima along roadsides and in disturbed areas throughout the park. This study will provide useful information on efficient methods to control Ailanthus altissima while maintaining the ecological integrity of the remaining plant community.

\section{HISTORY OF AILANTHUS ALTISSIMA}

Ailanthus altissima (tree-of-heaven) is a native of China. For the past 250 years, Ailanthus has rapidly spread through many regions of the western world. Ailanthus was first introduced into England and France in 1751 by a missionary who mistook it for a Japan varnish tree (Feret 1985). Ailanthus was brought to North America from two different sources. In the east, gardeners first brought the seeds from England in the late 1700s and planted them as ornamentals (Feret 1985). The second route was through the West Coast by Chinese immigrants who probably planted the Ailanthus seeds because of its cultural significance and medicinal uses (Hoshovsky 1995). By the mid 1800s, Ailanthus was a common nursery species in the eastern United States (Hoshovsky 1995). It began on urban and rural home sites and spread along 
transportation rights-of-way. Today the species can be found invading grasslands and disturbed forests throughout North America.

\section{Ecology-Biology}

Ailanthus altissima is an invasive pioneer species and rapidly spreads onto disturbed sites. The species is capable of prolific root and stump sprouting as well as producing a generous amount of seed. Both sprouts and seedlings experience rapid juvenile growth (Miller 1990). Ailanthus sprouts have been found to have 3 to $4 \mathrm{~m}$ of first-year height growth, while seedlings have been found to grow 1 to $2 \mathrm{~m}$ in the first year (Adamik and Braun 1957; Hu 1979; Miller 1990). This vigorous growth can continue for 4 or more years. The tree can reach a height of 15 to $24 \mathrm{~m}$ (Harlow et al. 1996) and does not appear to be limited by poor site conditions. It can tolerate a wide range of stoniness and pH (Miller 1990) as well as urban pollution (Feret 1985).

Ailanthus roots are shallow and spreading. Miller (1990) states that there is a general absence of a tap root. Most roots are present in the upper $46 \mathrm{~cm}$ of soil (Miller 1990). Roots develop near the soil surface, allowing for adventitious sprouting capability (Miller 1990). Although individual stems live only a short time (30 to 50 years), prolific seeding and sprouting ability allow for the formation of a dense thicket of stems that will persist for an indefinite amount of time. Ailanthus is a successful competitor with other pioneer species. If allowed to establish itself, Ailanthus will create a pure stand, with little opportunity for other plant species. Ailanthus has been found to produce allelopathic compounds in its bark and leaflets that are toxic to numerous woody and herbaceous species (Lawrence et al. 1991; Heisey 1996)

\section{Control Methods}

The methods used to control Ailanthus include manual, mechanical, burning, grazing, biocontrol, and chemicals (Hoshovsky 1995). No method can be deemed successful unless it can kill the roots or prevent additional sprouting.

Manual and mechanical methods include hand pulling young seedlings, cutting or chopping stems, girdling the stems, and hand digging the rootstocks (Hoshovsky 1995). Hand pulling can be performed on young seedlings but becomes impossible with a fully developed root system. Cutting and chopping stems is a common method used to control Ailanthus, but significant root and stump sprouting will result. Girdling the cambial tissue on the stem will kill the stem but also will lead to heavy root sprouting. Hand digging the rootstocks will control Ailanthus, but it is practical with small infestations only (Hoshovsky 1995). Burning and grazing can kill Ailanthus stems and weaken the roots, but neither method proves to be a long-term solution to the continuous sprouting.
Ailanthus altissima has very few disease and insect pests, so few biocontrol methods are currently available. Pathogens such as Verticillium spp. have the potential to become important fungal diseases (Feret 1985). Research is being conducted by R.J. Stipes of Virginia Tech to isolate strains of Fusarium spp. that may be useful as a mycoherbicide treatment.

Chemical methods are being used to control Ailanthus, but there is little research that provides accurate data on the different chemical application methods. Many herbicides can control or defoliate an Ailanthus stem. The most important criteria for any chemical treatment are successful control of root and stump sprouts and the eradication of established stems. A herbicide treatment needs to kill the Ailanthus stem while translocating down into the roots and preventing any further sprouting

\section{METHODS AND MATERIALS}

Test plots were established and treated in June 1997. The plots were located along Skyline Drive at the US 33 interchange and across from mile marker 101 in Shenandoah National Park. Troublesome Ailanthus altissima sprouts were located along roadsides in the park for the study. Nine treatments were applied: eight low-volume basal herbicide treatments plus a manual cutting (Table 1). Aqumix, Inc. (Cloverdale, VA), Eco-Pak LLC (Selma, IN), and Arborchem Products Co. (Mechanicsburg, PA) provided ready-to-use mixtures for this study. Four replicate plots were established for each treatment.

Each plot consisted of a 5 by $5 \mathrm{~m}$ square, containing a targeted minimum of ten established Ailanthus saplings or trees. The plots were delineated with tagged PVC stakes. A buffer was left between plots to avoid effects from surrounding plots. Herbaceous cover was visually estimated pre- and posttreatment over the entire plot for the three most dominant herbaceous species as well as total species presence or absence. Sequentially numbered tags identified each Ailanthus tree within the $5 \mathrm{~m}$ plot, and diameter at breast height (dbh) was measured for each tagged tree. Treatments were randomly assigned to each numbered plot for a randomized complete split-plot design.

Low-volume basal herbicide treatments were applied with a Solo ${ }^{\circledR}$ backpack sprayer using a solid cone nozzle at approximately 30 psi. Herbicide mixtures were applied to the lower 30 to $45 \mathrm{~cm}$ of each stem. Solutions were applied to wet the bark but not to the point of surface runoff. Complete coverage constituted wrapping of the solution around all sides of the stem surface. Approximately $3 \mathrm{~mL}$ of mixture was applied per inch of stem diameter.

Manual cutting was made with brush saws approximately 3 to 6 in. above ground level at the time of herbicide application.

Six weeks after treatment, visual estimations of defoliation were made to quantify short-term treatment effects. One year after treatment, in September 1998, diameters were mea- 
Table 1. Chemical treatments used to compare herbicide effectiveness with manual cutting for control of Ailanthus in Shenandoah National Park, Virginia.

\begin{tabular}{llll}
\hline Treatment code & Carrier system & Herbicide $^{*}$ & Herbicide rate (\% v/v) \\
\hline 1 & HY-Grade EC & Garlon 4 & 20 \\
2 & HY-Grade EC & Garlon 4 & 20 \\
& & Stalker & 1 \\
3 & HY-Grade EC & Garlon 4 & 15 \\
& & Stalker & 3 \\
4 & HY-Grade EC & Garlon 4 & 20 \\
& & Stalker & 3 \\
5 & Aqumix RTU & Garlon 4 & 20 \\
& & Tordon K & 5 \\
6 & Eco-Pak RTU & Garlon 4 & 20 \\
& & Tordon K & 5 \\
7 & Arborchem RTU & Garlon 4 & 20 \\
& & Tordon K & 5 \\
8 & HY-Grade EC & Stalker & 9 \\
9 & Manual cutting 7-15 & & \\
& cm above ground & & \\
\hline
\end{tabular}

"Garlon 4 (triclopyr @ 480 gae/L); Stalker (imazapyr @ 240 gae/L); Tordon K (picloram @ 240 gae/L). combined with a high Stalker rate $(3 \%$ $\mathrm{v} / \mathrm{v}$ ), to $100 \%$ defoliation for Garlon 4 alone and in Aqumix RTU. All other treatments were intermediate in defoliation.

Herbicide treatments to Ailanthus altissima greatly exceeded control and mortality over that induced by manual cutting of stems. Manual cutting averaged 1.6 new stump sprouts per stem, while none of the chemical treatments produced any stump sprouts. Only 21\% of cut stump trees failed to resprout, compared to $79 \%$ or greater mortality using chemical control methods.

Herbicide combinations that induced the highest mortality 1 year after treatment were Garlon 4 at 20\% v/v, 20\% Garlon 4 plus 5\% Tordon K (in either the Aqumix RTU or Eco-Pak RTU carrier), and 9\% Stalker in HY-Grade EC (Table 2). Similarly, 20\% Garlon 4 plus 1\% Stalker

sured of remaining live trees to determine mortality and control. Dead trees and manually cut trees were examined for stump sprouting. The percentage of control was determined using the change in diameter of live trees from 1997 to 1998 for chemical treatments according to the following:

$$
\text { Control \% = (dbh } 1997-\text { dbh 1998)/dbh } 1997 * 100
$$

Dead trees were assigned 100\% control. The percentage of control for manual cutting treatment was based on the number of stump sprouts emanating from the cut stump above groundline. Each stump sprout accounted for (-)100\% control according to the following:

$\%$ cut stump control $=(-) 100 *$ (number of sprouts)

In January 2000, a tally was taken of the number of Ailanthus stems in each plot and converted to the number of stems per acre.

Native grass and herbaceous species seed mixtures were considered but not applied after determining that posttreatment effects included a shift from non-native species to those common in the Shenandoah region. Data were analyzed using ANOVA, and means were separated by LSD at the $\alpha=0.05$ significance level. Stem counts 2 years after treatment were analyzed by box plot because the treatment variance precluded use of ANOVA.

\section{RESULTS AND DISCUSSION}

Defoliation 6 weeks after treatment indicated variable effects for all treatments except manual cutting (Table 2). Defoliation ranged from $75 \%$ for the low rate ( $15 \% \mathrm{v} / \mathrm{v})$ of Garlon 4 and 20\% Garlon 4 plus 5\% Tordon K (Arborchem RTU) approached 100\% mortality. While Arborchem RTU and 20/1 Garlon/Stalker mixtures did not result in significantly lower mortality than the aforementioned treatments, persistent live trees could be the result of incomplete application rather than chemical ineffectiveness. Chemical combinations that did not control Ailanthus as well as other treatments were 15\% Garlon 4 plus 3\% Stalker and 20\% Garlon 4 plus 5\% Stalker.

Garlon 4 at 20\% and 9\% Stalker, when applied independently, successfully controlled Ailanthus. When combined, the control was slightly decreased. Statistically, there were no differences among any of the RTU mixes. Garlon or Stalker alone or in mixtures with low rates (1\%) of Stalker, and any of the Garlon/Tordon RTUs, provided adequate control of Ailanthus over manual cutting.

Overall stem reduction was assessed 2 years after treatment. ANOVA was not used due to the lack of treatment variance homogeneity. Data are presented using box plot analysis. There was no difference among the RTU mixes, but the differences among the treatments containing picloram and the others were observed with the reduction in treatment variance being very evident. While the Garlon and Garlon plus Stalker treatments were similar, all treatments reduced the overall stem count when compared to cutting alone (Figure 1). Stalker alone at 9\% provided intermediate control between the RTU mixes and the Garlon + Stalker mixes.

Herbaceous species present on the plots prior to treatment consisted largely of garlic mustard (Alliaria petiolata) along with native herbaceous plants (Table 3). Either as a result of the removal of Ailanthus, or due to natural species shifts, garlic mustard, a non-native plant, was absent 1 year later and was replaced by predominantly native species. Dominant species 
present over all four blocks largely consisted of native wildflowers, including Joe Pye weeds (Eupatorium spp.), Dutchman's pipe (Aristolochia durior), and jewelweed (Impatiens capensis), among others. Once Ailanthus was removed, reseeding with native herbaceous species was not necessary.

One interesting note regarding herbaceous species composition was the dominant vegetation surrounding the rock wall that lies along Skyline Drive near the US 33 interchange between the road and treatment plots. Prior to treatment (June 1997), roadside herbaceous vegetation was dominated by bouncing bet (Saponaria officinalis), introduced from Europe. At the time of post-treatment measurements (early September 1998), bouncing bet was either absent altogether or only a minor component of the roadside vegetation (Table 4). This finding suggests natural shifts in herbaceous vegetation independent of Ailanthus control.

\section{SUMMARY AND CONCLUSION}

Manual cutting of Ailanthus stimulated resprouting and increased overall stand density. Chemical control not only removed existing trees but also prevented resprouting by eliminating the existing root system. Optimal herbicide treatments for control of
Ailanthus should include combination with 5\% Tordon K. Garlon 4 at 20\% v/v alone, Garlon 4 combined with Stalker, or Stalker alone controlled Ailanthus better than hand cutting but were not as effective as treatments containing picloram.

Removal of Ailanthus resulted in a shift in herbaceous species to native species of the region without having to reseed with naturally occurring herbs.

Manual control of Ailanthus should be avoided in order to prevent proliferation throughout the park. Herbicide control of Ailanthus would be the preferred method of control because it not only successfully kills the trees, but it also prevents resprouting. Because major Ailanthus infestations occur near roadways, access with a backpack sprayer should not be a major concern.

\begin{tabular}{|c|c|c|}
\hline & Treatment & $\begin{array}{l}\text { Mean Stems Per } \\
\text { Acre } 2 \text { YAT }\end{array}$ \\
\hline Manual Cutting - & $\begin{array}{r}\text { Manual cutting } 7-15 \mathrm{~cm} \text { above } \\
\text { ground }\end{array}$ & 5645 \\
\hline Stalker $9 \%-6$ & Stalker $9 \%$ in $\mathrm{HY}$-Grade EC & 363 \\
\hline $\begin{array}{l}\text { Arborchem RTU }- \text { E } \\
\text { ECO-PAK RTU }-\mathbb{B}\end{array}$ & $\begin{array}{r}\text { Garlon } 420 \%+5 \% \text { Tordon K in } \\
\text { Arborchem RTU }\end{array}$ & 81 \\
\hline $\begin{array}{r}\text { AQUMIX RTU } \\
\text { Garlon } 4 \text { + Stalker 20+3\% }\end{array}$ & $\begin{array}{r}\text { Garlon } 420 \%+5 \% \text { Tordon K in } \\
\text { ECO-PAK RTU }\end{array}$ & 81 \\
\hline $\begin{array}{l}\text { Garlon } 4+\text { Stalker } 15+3 \% \\
\text { Garlon } 4+\text { Stalker } 20+1 \%\end{array}$ & $\begin{array}{r}\text { Garlon } 420 \%+5 \% \text { Tordon K in } \\
\text { AQUMIX RTU }\end{array}$ & 121 \\
\hline Garlon 4 20\% & $\begin{array}{r}\text { Garlon } 420 \%+3 \% \text { Stalker in } \\
\text { HY-Grade EC }\end{array}$ & 1089 \\
\hline $\begin{array}{c}0 \quad 100020003000400050006000700080008000 \\
\text { stems per acre }\end{array}$ & $\begin{array}{r}\text { Garlon } 415 \%+3 \% \text { Stalker in } \\
\text { HY-Grade EC }\end{array}$ & 766 \\
\hline Black dot represents the mean value, the vertical line near mean & $\begin{array}{r}\text { Garlon } 420 \%+1 \% \text { Stalker in } \\
\text { HY-Grade EC }\end{array}$ & 1331 \\
\hline $\begin{array}{l}\text { represents the median value, the rectangular box represents roughly } \\
50 \% \text { of the middle data, and the horizontal lines (tails) represent the } \\
\text { extent of the data. }\end{array}$ & Garlon $420 \%$ in HY-Grade EC & 685 \\
\hline
\end{tabular}

Figure 1. Box plot of stem count (number of stems per acre) as affected by treatments. Untreated is hand-cut only. 
Table 3. Pre-treatment dominant herbaceous species over all four blocks by treatment for Ailanthus control plots on Skyline Drive in Shenandoah National Park, Virginia.

\begin{tabular}{|c|c|c|}
\hline Treatment & Overall three most dominant species & Average \% cover* \\
\hline \multirow[t]{3}{*}{ Garlon 4 20\% in HY-Grade EC } & Alliaria petiolata (garlic mustard) & 58 \\
\hline & Impatiens capensis (jewelweed) & 40 \\
\hline & Aristolochia durior (Dutchman's pipe) & 40 \\
\hline Garlon $420 \%+1 \%$ Stalker in & Alliaria petiolata (garlic mustard) & 67 \\
\hline \multirow[t]{2}{*}{ HY-Grade EC } & Osmorhiza longistylis (sweet cicely) & 40 \\
\hline & Arctium minus (burdock) & 32 \\
\hline Garlon $415 \%+3 \%$ Stalker in & Alliaria petiolata (garlic mustard) & 57 \\
\hline \multirow[t]{2}{*}{ HY-Grade EC } & Impatiens capensis (jewelweed) & 40 \\
\hline & Hydrophyllum virginianum (Virginia waterleaf) & 20 \\
\hline Garlon $420 \%+3 \%$ Stalker in & Alliaria petiolata (garlic mustard) & 57 \\
\hline \multirow[t]{2}{*}{ HY-Grade EC } & Arctium minus (burdock) & 30 \\
\hline & Toxicodendron radicans (poison ivy) & 15 \\
\hline \multirow{3}{*}{$\begin{array}{l}\text { Garlon } 420 \%+5 \% \text { Tordon } \mathrm{K} \\
\text { in CWC basal mix RTU }\end{array}$} & Alliaria petiolata (garlic mustard) & 75 \\
\hline & Eupatorium spp. (Joe Pye weed) & 27 \\
\hline & Impatiens capensis (jewelweed) & 20 \\
\hline \multirow{3}{*}{$\begin{array}{l}\text { Garlon } 420 \%+5 \% \text { Tordon } \mathrm{K} \\
\text { in Exacto RTU }\end{array}$} & Alliaria petiolata (garlic mustard) & 60 \\
\hline & Bromus sterillis (bromegrass) & 50 \\
\hline & Arctium minus (burdock) & 20 \\
\hline \multirow{3}{*}{$\begin{array}{l}\text { Garlon } 420 \%+5 \% \text { Tordon } \mathrm{K} \\
\text { in Arborchem RTU }\end{array}$} & Alliaria peiolata (garlic mustard) & 62 \\
\hline & Impatiens capensis (jewelweed) & 20 \\
\hline & Arctium minus (burdock) & 20 \\
\hline \multirow[t]{3}{*}{ Stalker $9 \%$ in HY-Grade EC } & Alliaria petiolata (garlic mustard) & 67 \\
\hline & Gillenia trifoliata (bowman's root) & 20 \\
\hline & Aristolochia durior (Dutchman's pipe) & 20 \\
\hline \multirow{3}{*}{$\begin{array}{l}\text { Manual cutting } 3 \text { in. above } \\
\text { ground }\end{array}$} & Alliaria petiolata (garlic mustard) & 67 \\
\hline & Osmorhiza longistyllis (sweet cicely) & 30 \\
\hline & Arctium minus (burdock) & 20 \\
\hline
\end{tabular}

${ }^{*}$ Average cover may be greater than $100 \%$ because coverage was averaged over four blocks by species.

\section{LITERATURE CITED}

Adamik, K., and F.E. Braun. 1957. Ailanthus altissima as pulpwood. TAPPI 40:522-526.

Feret, P.P. 1985. Ailanthus: Variation, cultivation, and frustration. J. Arboric. 11(12):361-368.

Harlow, W.H., E.S. Harrar, J.W. Hardin, and F.M. White. 1996. Textbook of Dendrology (8th ed.). McGraw-Hill, New York, NY, pp. 459-460.

Heisey, R.M. 1996. Identification of an allelopathic compound from Ailanthus altissima (Simaroubaceae) and characterization of its herbicidal activity. Am. J. Bot. 83(2):192-200.

Hoshovsky, M.C. 1995. Ailanthus altissima: Element Stewardship Abstract. http://www.conserveonline.org/ subjects.

Hu, S. 1979. Ailanthus. Arnoldia 39(2):29-50.

Lawrence, J.G., A. Colwell, and O.J. Sexton. 1991. The ecological impact of allelopathy in Ailanthus altissima (Simaroubaceae). Am. J. Bot. 78(7):948-958.

Miller, J.H., 1990. Ailanthus altissima, pp. 101-105. In Burns, R.M. and B.H. Honkala (Eds.). Silvics of North America, Vol. 2: Hardwoods. USDA Agricultural Handbook \#654. Stipes, R.J. 1995. A tree grows in Virginia. Va. J. Sci. 46:105.
Acknowledgments. We gratefully acknowledge the cooperation of James Akerson, forest ecologist, and the National Park Service for making this study possible. We also acknowledge Meral Jackson and Matt Nespeca for assistance with the fieldwork.

Tordon $\mathrm{K}$ and Garlon 4 are trademarks of Dow Agrosciences, LLC. Stalker is a trademark of BASF. HY-Grade basal oil is a trademark of CWC Chemical, Cloverdale, VA.

${ }^{1 *}$ Field Research Biologist

Dow AgroSciences, LLC

3425 Elk Creek Drive

Christiansburg, VA 24073, U.S.

${ }^{2}$ Professor

Virginia Tech

22B Cheatham Hall

Blacksburg, VA 24061, U.S.

${ }^{*}$ Corresponding author. 
Table 4. Post-treatment dominant herbaceous species over all four blocks by treatment for Ailanthus control plots on Skyline Drive in Shenandoah National Park, Virginia.

\begin{tabular}{|c|c|c|}
\hline Treatment & Overall three most dominant species & Average $\%$ cover $^{2}$ \\
\hline \multirow[t]{3}{*}{ Garlon 4 20\% in HY-Grade EC } & Impatiens capensis (jewelweed) & 60 \\
\hline & Mixed grasses ${ }^{y}$ & 30 \\
\hline & Eupatorium spp. (Joe Pye weed) & 20 \\
\hline Garlon $420 \%+1 \%$ Stalker in & Mixed grasses & 40 \\
\hline \multirow[t]{2}{*}{ Hy-Grade EC } & Aristolochia durior (Dutchman's pipe) & 30 \\
\hline & Impatiens capensis (jewelweed) & 25 \\
\hline Garlon $415 \%+3 \%$ Stalker in & Arctium minus (burdock) & 40 \\
\hline \multirow{2}{*}{ Hy-Grade EC } & Impatiens capensis (jewelweed) & 31 \\
\hline & Aristolochia durior (Dutchman's pipe) & 20 \\
\hline Garlon $420 \%+3 \%$ Stalker in & Mixed grasses & 40 \\
\hline \multirow[t]{2}{*}{ HY-Grade EC } & Impatiens capensis (jewelweed) & 30 \\
\hline & Eupatorium spp. (Joe Pye weed) & 30 \\
\hline \multirow{3}{*}{$\begin{array}{l}\text { Garlon } 420 \%+5 \% \text { Tordon } \mathrm{K} \\
\text { in HY-Grade EC }\end{array}$} & Mixed grasses & 40 \\
\hline & Impatiens capensis (jewelweed) & 30 \\
\hline & Eupatorium spp. (Joe Pye weed) & 30 \\
\hline \multirow{3}{*}{$\begin{array}{l}\text { Garlon } 420 \%+5 \% \text { Tordon K } \\
\text { in CWC basal nix RTU }\end{array}$} & Mixed grasses & 40 \\
\hline & Aristolochia durior (Dutchman's pipe) & 40 \\
\hline & Eupatorium spp. (Joe Pye weed) & 30 \\
\hline \multirow{3}{*}{$\begin{array}{l}\text { Garlon } 420 \%+5 \% \text { Tordon } \mathrm{K} \\
\text { in Exacto RTU }\end{array}$} & Eupatorium spp. (Joe Pye Weed) & 50 \\
\hline & Impatiens capensis (jewelweed) & 40 \\
\hline & Mixed grasses & 30 \\
\hline \multirow{3}{*}{$\begin{array}{l}\text { Garlon } 420 \%+5 \% \text { Tordon K } \\
\text { in Arborchem RTU }\end{array}$} & Mixed grasses & 50 \\
\hline & Impatiens capensis (jewelweed) & 40 \\
\hline & Sanguinara canadensis (bloodroot) & 30 \\
\hline \multirow[t]{3}{*}{ Stalker 9\% in Hy-Grade EC } & Impatiens capensis (jewelweed) & 37 \\
\hline & Verbascum thapsus (mullein) & 30 \\
\hline & Arctium minus (burdock) & 30 \\
\hline \multirow{3}{*}{$\begin{array}{l}\text { Manual cutting } 3 \text { in. above } \\
\text { ground }\end{array}$} & Impatiens capensis (jewelweed) & 30 \\
\hline & Eupatorium spp. (Joe Pye weed) & 10 \\
\hline & Aristolochia durior (Dutchman's pipe) & 5 \\
\hline
\end{tabular}

${ }^{z}$ Average cover may be greater than $100 \%$ because coverage was averaged over four blocks by species.

${ }^{y}$ Mixed grasses consisted of Danthonia, Poa, Agrostis, Dactylis, Festuca, and Panicum spp.

Résumé. Huit traitements avec des herbicides ont été utilisés au moyen d'applications basales à faibles volumes et ont été ensuite comparés à la coupe manuelle pour l'éradication de l'Ailanthus altissima. La coupe manuelle de l'Ailanthus a stimulé la production de rejets et accrue la densité globale du peuplement. Le contrôle chimique n'a pas seulement éliminé les arbres existants, mais a aussi prévenu la formation de rejets. Suite à une évaluation effectuée deux années après le traitement, on a constaté que le contrôle optimum de l'Ailanthus était atteint avec une combinaison d'herbicides que sont le Garlon 4 et le Tordon K. Le Garlon 4 seul à 20\% (v/v), le Garlon 4 combiné avec le Stalker, ou encore le Stalker seul, contrôlaient de façon supérieure l'Ailanthus que la coupe manuelle, mais ils n'étaient pas aussi efficaces que les traitements qui contenaient du picloram. Léradication de l'Ailanthus a produit un changement des espèces herbacées indigènes vers des espèces introduites, et ce dans les régions où il n'y avait pas de réensemencement provenant d'herbacées naturellement présentes. Le contrôle manuel de l'Ailanthus devrait être évité afin de prévenir la prolifération sur l'ensemble du site. Le contrôle par herbicide de l'Ailanthus est la méthode de contrôle préférable étant donné qu'il détruit avec succès les arbres et prévient la formation de rejets. Du fait que les infestations majeures par l'Ailanthus se produisent près des routes, l'accès avec un réservoir dorsal devrait être réalisable.

Zusammenfassung. Bei der Entfernung von Ailanthus wurde 8 verschiedene Herbizidanwendungen in einer basalen Applikation mit manuellem Rückschnitt verglichen. Manueller Rückschnitt stimulierte einen Wiederausschlag der Knospen und vergrößerte die Dichte des Bestands. Die chemische Kontrolle verminderte nicht nur vorhandene Bäume, sondern verhinderte auch das Austreiben von Knospen. In einer Bewertung nach zwei Jahren wurde eine optimale Kontrolle bei einer Kombination von Garlon 4 und Tordon K erreicht. Garlon 4 bei 20\% v/v allein, Garlon 4 
kombiniert mit Stalker oder Stalker alleine kontrollierte Ailanthus besser als manueller Rückschnitt, aber sie waren weniger effektiv als Behandlungen, die Picloram enthielten. Die Entfernung von Ailanthus führte zu einer Veränderung der Artenzusammensetzung zum Vorteil der endemischen Pflanzen, ohne diese nachsäen zu müssen. Die Herbizidkontrolle ist die bevorzugte Kontrollmethode, weil es auf die Dauer erfolgreich abtötet und ein Nachkeimen unterdrückt. Da größere Ailanthus bestände neben Straßen vorkommen, kann ein Zugriff mit Rückenspritzen empfohlen werden.

Resumen. Se compararon ocho tratamientos con herbicida en aplicaciones basales de bajo volumen comparadas con remoción manual de Ailanthus altissima. Las cortas manuales de Ailanthus estimularon el rebrote e incrementaron la densidad. El control químico no solamente eliminó los árboles existentes, sino que también previno el rebrote. Cuando se evaluaron los tratamientos, dos años después, el control óptimo de Ailanthus fue mejorado con una combinación de los herbicidas Garlon 4 y Tordon H. Garlon 4 al 20\% v/v solo, Garlon 4 combinado con herbicida Stalker o Stalker solo, controló Ailanthus mejor que las cortas manuales pero no fue tan efectivo como los tratamientos que contenían picloram. La remoción de Ailanthus resultó en un cambio de especies herbáceas a especies nativas de la región sin la regeneración natural de herbáceas. El control manual de Ailanthus debe evitarse con el fin de prevenir su proliferación en el parque. El control herbicida de Ailanthus es el método preferido de control. Debido a que las infestaciones de Ailanthus se presentan cerca de las carreteras, debe llevarse a cabo el trabajo con una mochila aspersora. 